\title{
Triglyceride-Glucose index as a surrogate marker for insulin resistance in obese adolescents
}

\section{Obez adolesanlarda insülin direncinin göstergesi olarak olarak Trigliserit-Glikoz indeksi}

\author{
Hüiseyin Taştanoğlü ${ }^{1}$, Nurullah Çelik ${ }^{2}$
}

Zara Devlet Hastanesi, Çocuk Sağlığı ve Hastalıkları, Zara/Sivas, Türkiye

${ }^{2}$ Sivas Cumhuriyet Üniversitesi Tıp Fakültesi Çocuk Sağlı̆̆ ve Hastalıkları Anabilim Dalı, Çocuk Endokrinoloji Bilim Dalı, Sivas, Türkiye Corresponding author: Nurullah Çelik, MD, Sivas Cumhuriyet Üniversitesi Tıp Fakültesi Çocuk Sağlığı ve Hastalıkları Anabilim Dalı, Çocuk Endokrinoloji Bilim Dalı, Sivas, Türkiye

E-mail: celiknurullah@hotmail.com

Received/Accepted: November 13,2021/December 09, 2021

Conflict of interest: There is not a conflict of interest.

\section{SUMMARY}

Objective: There is a lot of study in adults investigating the TriglycerideGlucose (Ty-G) index. However, a limited study has been searched in the pediatric age group. Moreover, to the best of our knowledge, there is no study on Turkish children. The aim of this study, to investigate the usability of the triglyceride-glucose index as an indicator of insulin resistance in obese adolescents and to calculate the cut-off values.

Method: Six hundred twenty-three pubertal obese adolescents (266 boys, and 357 girls) were retrospectively evaluated. Ty-G index and HOMA-IR levels were calculated. ROC analysis was used for the estimations of the Ty-G index cutoff value.

Results: There was positive correlation between HOMA-IR and Ty-G index in boys $(r=0.255, p<0.001)$, in girls $(r=0.402, p<0.001)$, and all study groups $(\mathrm{r}=0.323, \mathrm{p}<0.001)$. Ty-G index cutoff value for insülin resistance in pubertal obese adolescents was calculated as 8.42 with $70.1 \%$ sensitivity and $59.3 \%$ specificity for all study groups; 8,38 with $71.1 \%$ sensitivity, and $48.3 \%$ specificity for boys; 8,27 with $80 \%$ sensitivity, and $52.9 \%$ specificity for girls.

Conclusions: Ty-G index may be a reliable indicator for insülin resistance in pubertal obese adolescents. More attention should be given fort his marker with prospective studies.

Keywords: Insulin resistance, Triglyceride-Glucose index, HOMA-IR, obesity, adolescents.

\section{Hüseyin Taştanoğlu}

Nurullah Çelik

ORCID IDs of the authors: H.T. 0000-0002-6034-9998 N.Ç. 0000-0003-1583-6807 
ÖZET

Amaç: Trigliserit-Glikoz (Ty-G) indeksini araştıran yetişkinlerde çok sayıda çalışma olmasına rağmen çocukluk yaş grubunda sınırlı sayıda çalışma vardır. Ayrıca bildiğimiz kadarıyla Türk çocukları ile ilgili bir çalışma bulunmamaktadır. Bu çalışmanın amacı, obez adolesanlarda Ty-G indeksinin insülin direncinin bir göstergesi olarak kullanılabilirliğini araştırmak kesme değerlerini hesaplamaktır.

Yöntem: Altı yüz yirmi üç obez ergen (266 erkek ve 357 kı) geriye dönük olarak değerlendirildi. Ty-G indeksi ve HOMA-IR seviyeleri hesaplandı. Ty-G indeks kesme değerinin tahminleri için ROC analizi kullanıldı.

Bulgular: Erkeklerde $(r=0.255, p<0.001)$, kızlarda $(r=0.402, p<0.001)$ ve tüm çalışma gruplarında $(r=0.323, p<0.001)$ HOMA-IR ile Ty-G indeksi arasında pozitif korelasyon vardı. Pubertal obez ergenlerde insülin direnci için Ty-G indeksi eşik değeri tüm çalışma grupları için \%70.1 duyarl111k ve \%59.3 özgüllük ile 8.42 olarak; erkek adolesanlar için \%71,1 duyarlılık ve \%48,3 özgüllük ile 8,38 olarak; kızlar için \%80 duyarlılık ve \%52.9 özgüllük ile 8,27 olarak hesaplandı.

Sonuç: Ty-G indeksi pubertal obez ergenlerde insülin direnci için güvenilir bir gösterge olabilir. Bu konuda prospektif çalışmalara ihtiyaç vardır.

Anahtar sözcükler: İnsülin direnci, Trigliserit-Glikoz İndeksi, HOMA-IR, obezite, ergen.

\section{INTRODUCTION}

Obesity is a chronic disease that has an increasing prevalence in both developed and developing countries and affects adults and children ${ }^{1}$. Therefore, prevention and treatment of obesity and early recognition of obesity-related diseases have gained importance.

Obesity is an important risk factor for the development of some chronic diseases such as insulin resistance, hypertension, and type 2 diabetes $^{2-3}$. Insulin sensitivity is inversely related to body mass index and body fat. Insulin resistance can be defined as impairment of the normal biological response to both endogenous and exogenous insulin. One of the primary defects underlying the development of type 2 diabetes is thought to be insulin resistance. So, it is present in $85 \%$ of these patients with Type 2 DM. It is also related to the pathogenesis of many illnesses which includes coronary heart disease, and hypertension 4 .

There are several methods for measuring $\mathrm{IR}^{5-7}$. The hyperinsulinemic-euglycemic clamp test is accepted as a gold standard method though it is too complex and time-consuming method ${ }^{5}$. So, some mathematical formulas have been developed for measuring insulin sensitivity. One of the most widely used methods is the Homeostatic Model Assessment of Insulin Resistance (HOMA-IR), which is calculated using fasting glucose and fasting insulin ${ }^{6}$. The biggest limitation of the HOMA-IR test is that insulin cannot be studied in every center, especially in primary care centers. Therefore, it was needed a simple, reliable, and less costly method of measuring insulin resistance. Simental-Mendia et al. developed the Ty-G index ${ }^{7}$. The Ty-G index is a calculation method measured using triglyceride and fasting blood glucose.
Studies have shown that insulin resistance measured by the hyperinsulinemic-euglycemic clamp method is highly correlated with HOMA$\mathrm{IR}^{7-8}$. It was reported that the Ty-G index showed a higher correlation with the hyperinsulinemiceuglycemic clamp test compared to the HOMA$\mathrm{IR}^{5-9}$. However, there are limited studies on the use of the Ty-G index as an indicator of insulin resistance in the pediatric population.

The study is to investigate the usability of the Ty$G$ index as an indicator of insulin resistance in obese adolescents and to try to determine the cutoff values.

\section{MATERIAL AND METHODS}

The study was conducted at Sivas Cumhuriyet University Medical Faculty. The population of the study consisted of 623 pubertal obese children (266 boys, 357 girls) aged 10-18 years old. Patients were selected retrospectively from the pediatric endocrinology department archive between January 2015 to January 2021. Body mass index (BMI) was calculated according to the formula [weight $(\mathrm{kg}) /$ height $(\mathrm{m})^{2}$ ]. Weight, height, and BMI are expressed as the z-score. Obesity was defined as a BMI above the 95th percentile for the sex and age, according to percentile charts for Turkish children ${ }^{10}$. Children who have the chronic disorder or secondary obesity, prepubertal status, used any medication were excluded.

\section{Laboratory analysis}

Overnight fasting blood samples were obtained between 8:00 and 8:30 a.m. in serum-separating gel tubes (Becton Dickinson, UK). Glucose, total cholesterol, triglyceride, low-density lipoprotein cholesterol (LDL), and high-density lipoprotein cholesterol (HDL) levels were measured using a colorimetric method (Roche Cobas, c702, 
Germany). Insulin levels were measured using the electrochemiluminescence method (Roche Cobas e801, Germany).

\section{Calculations}

1. Triglyceride Glucose index (Ty-G İndex): it was calculated as the following formula ${ }^{7}$

"Ln[fasting triglycerides $(\mathrm{mg} / \mathrm{dl}) \times$ fasting plasma glucose (mg/dl)/2])"

2. Homeostasis Model of Insulin Resistance (HOMA-IR): According to the HOMA-IR level, the threshold value for insulin resistance was taken as 3.82 in girls and 5.22 in boys ${ }^{11}$. It was calculated using the following formula ${ }^{6}$.

"HOMA-IR=[FastinG insulin level $(\mu U / m L) x F a s t i n g$ glucose level $(\mathrm{mg} / \mathrm{dL}) \mathrm{J} / 405]$ ]"

\section{Statistical analyses}

Statistical analyses of the data were carried out with Statistical Package for Social Sciences (SPSS/PC 16.0) for Windows software (SPSS, Chicago, IL, USA). The results were analyzed using the percentage distribution for qualitative data and mean (standard deviation) for quantitative data. The statistical tests included the ShapiroWilks test for normality, the chi-square test for comparisons of qualitative data among groups, and the independent samples $t$-test of quantitative data among gender groups. The correlations between quantitative data were calculated by Pearson rank correlations. ROC analysis was used for the estimations of the Ty-G İndex cutoff value. The significance level was accepted as $\mathrm{p}<0.05$.

The institutional ethics committee approved the study protocol (20.10.2021/2021-10/02).

\section{RESULTS}

The mean age of the study population was $13.31 \pm 1.98$ years $(13.11 \pm 1.92$ for boys, $13,45 \pm 2,02$ for girls, $\mathrm{p}=0.03$ ). Forty-two percent of the study population $(\mathrm{n}=357)$ was girl. Weight, weight-SDS, Height, height-SDS, BMI, and BMISDS levels were shown in Table 1 . When we compared according to genders, serum glucose $(89,48 \pm 7,31$ vs. $87,56 \pm 7,66 \mathrm{mg} / \mathrm{dL})$, and cholesterol $(158,66 \pm 32,81$ vs. $152,77 \pm 28,79)$ levels were higher in boys than girls $(\mathrm{p}=0.002$ and $\mathrm{p}=0.01$, respectively). However, serum insülin, HDL, LDL, and triglyceride levels were similar (p>0.05). (Table1.)

Table 1. Basal metabolic and metabolic parameters of the study group

\begin{tabular}{|l|c|c|c|c|}
\hline & All & Boys & Girls & $\mathrm{p}$ \\
\hline Age, year & $13.31 \pm 1.98$ & $13.11 \pm 1.92$ & $13,45 \pm 2,02$ & 0,03 \\
\hline Sex & & $\% 58$ & $\% 42$ & $<0,01$ \\
\hline Body-weight, $k g$ & $72,59 \pm 18,32$ & $74,94 \pm 20.59$ & $70,83 \pm 16,24$ & $<0.001$ \\
\hline Body-weight-SDS & $2,58 \pm 0,92$ & $2,42 \pm 0,83$ & $2,70 \pm 0,96$ & $<0.001$ \\
\hline Height, $c m$ & $155,42 \pm 12,58$ & $156,79 \pm 13,61$ & $154,39 \pm 11,67$ & 0,01 \\
\hline Height-SDS & $0,49 \pm 1,15$ & $0,73 \pm 1,07$ & $0,31 \pm 1,17$ & $<0,001$ \\
\hline BMI, $\mathrm{kg} / \mathrm{cm}^{2}$ & $29,68 \pm 4,09$ & $29,90 \pm 4,07$ & $29,51 \pm 4,11$ & 0,24 \\
\hline BMI-SDS & $2,47 \pm 0,53$ & $2,37 \pm 0,48$ & $2,55 \pm 0,55$ & $<0,001$ \\
\hline Glucose, $m g / d L$ & $88,37 \pm 7,57$ & $89,48 \pm 7,31$ & $87,56 \pm 7,66$ & 0,002 \\
\hline Insulin, $U u / m L$ & $23,36 \pm 13,95$ & $23,14 \pm 16,57$ & $23,53 \pm 11,64$ & 0,73 \\
\hline Cholesterol, $m g / d L$ & $155,29 \pm 30,69$ & $158,66 \pm 32,81$ & $152,77 \pm 28,79$ & 0,01 \\
\hline HDL, $m g / d L$ & $43,97 \pm 10,66$ & $43,01 \pm 9,62$ & $44,68 \pm 11,33$ & 0,05 \\
\hline LDL, $m g / d L$ & $97,28 \pm 27,51$ & $99,36 \pm 27,57$ & $95,69 \pm 27,39$ & 0,11 \\
\hline Triglyceride, $m g / d L$ & $120,12 \pm 53,05$ & $121,98 \pm 58,01$ & $118,73 \pm 49,03$ & 0,45 \\
\hline HOMA-IR & $5,16 \pm 3,28$ & $5,19 \pm 3,88$ & $5,14 \pm 2,75$ & 0,84 \\
\hline TG-Index & $8,47 \pm 0,46$ & $8,48 \pm 0,501$ & $8,46 \pm 0,44$ & 0,66 \\
\hline
\end{tabular}

HOMA-IR levels of the all study group was $5,16 \pm 3,28$. When we compared HOMA-IR levels in boys and girls, there is no statistically significant difference $(5,19 \pm 3,88$ vs $5,14 \pm 2,75 ; \mathrm{p}>0.05)$. Similarly, Ty-G index levels were also similar in the groups $(8,47 \pm 0,46$ for all study groups, $8,48 \pm 0,501$ for boys, and $8,46 \pm 0,44$ for girls; $\mathrm{p}>0.05$ ). (Table 1, Figure 1).

When we evaluated the correlations between HOMA-IR and Ty-G index; there were statistically 
significant positive correlations in boys $(\mathrm{r}=0.255$, $\mathrm{p}<0.001)$, girls $(\mathrm{r}=0.402, \mathrm{p}<0.001)$, and all study groups ( $r=0.323, p<0.001$ ), (Figure 2). It has been also shown that HOMA-IR level was positively correlated with age, BMI-SDS, Glucose, insülin, and triglyceride; negatively correlated with HDL levels. On the other hand, there was a weak correlation between Ty-G İndex with insülin, cholesterol LDL, and HDL levels (Table 2).
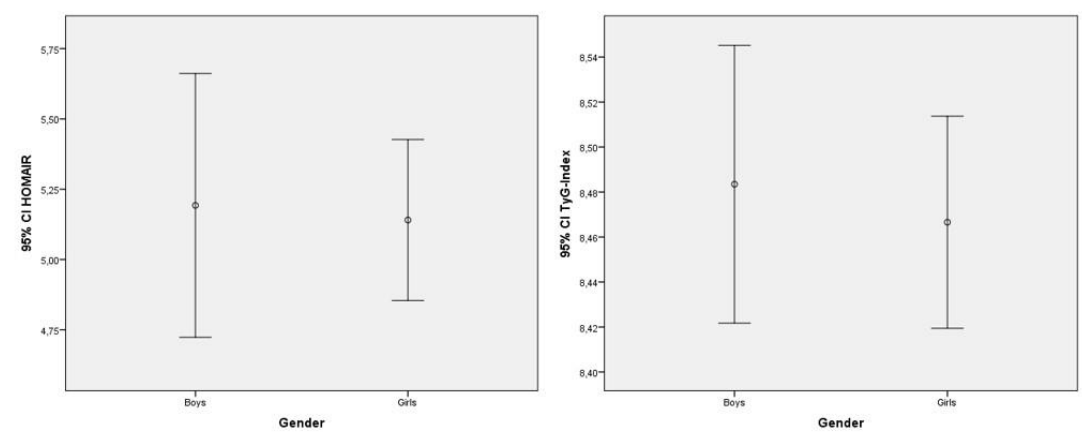

Figure 1: Comparison of the HOMA-IR and Ty-G index according to gender
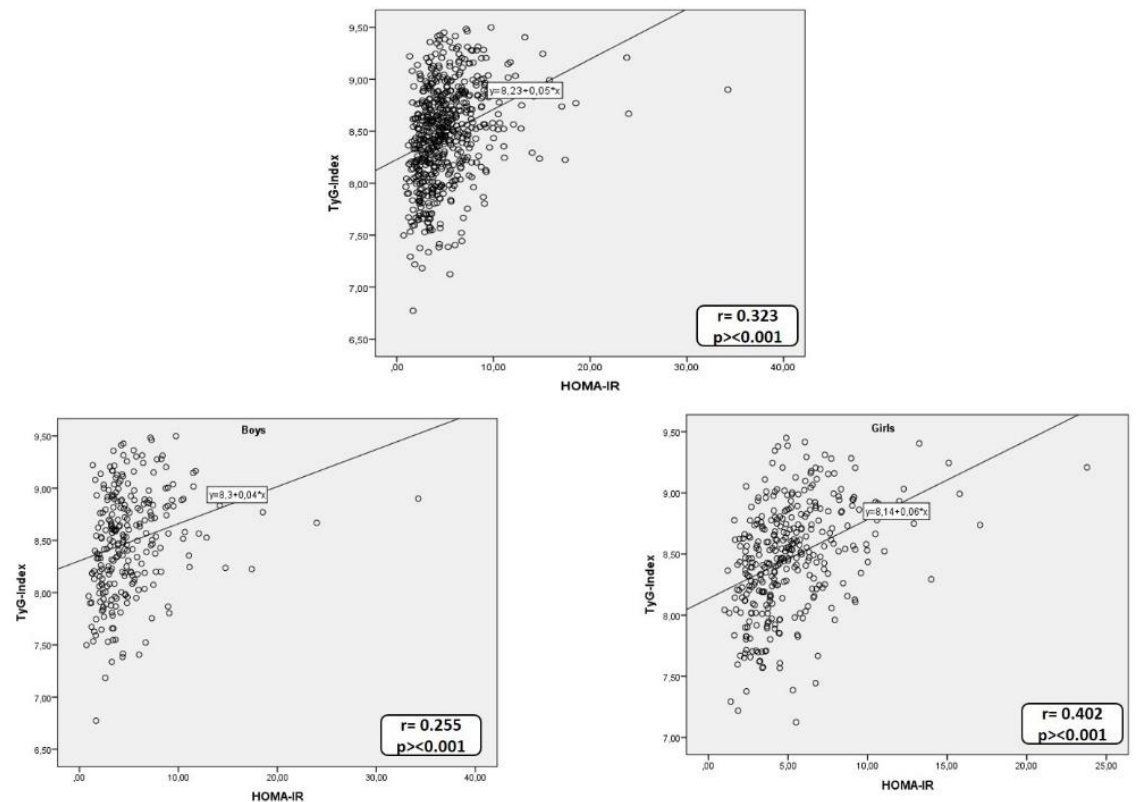

Figure 2: Correlations between HOMA-IR and Ty-G index; there were statistically significant positive correlations in boys $(\mathrm{r}=0.255, \mathrm{p}<0.001)$, girls $(\mathrm{r}=0.402, \mathrm{p}<0.001)$, and all study groups $(\mathrm{r}=0.323, \mathrm{p}<0.001)$ 
Table 2: Pearson correlation coefficients between HOMA-IR and Ty-G index with metabolic parameters

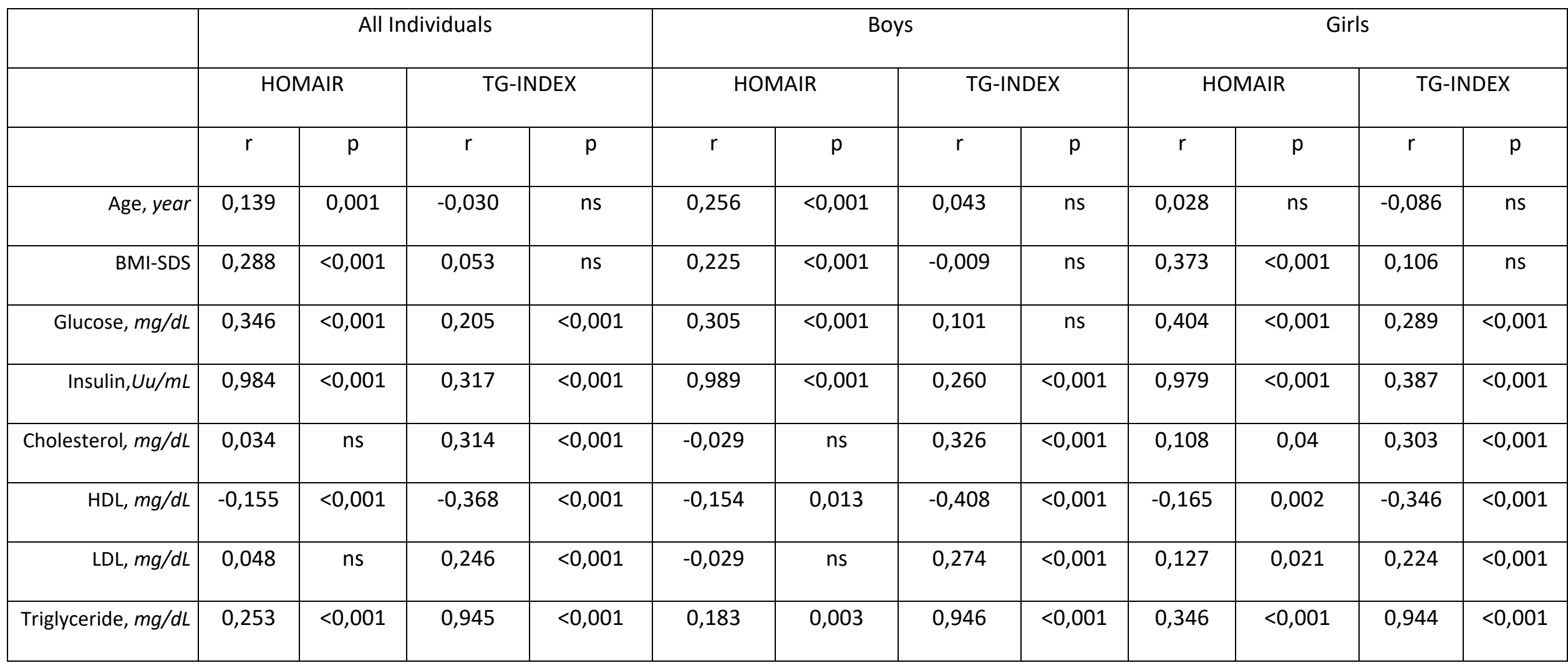



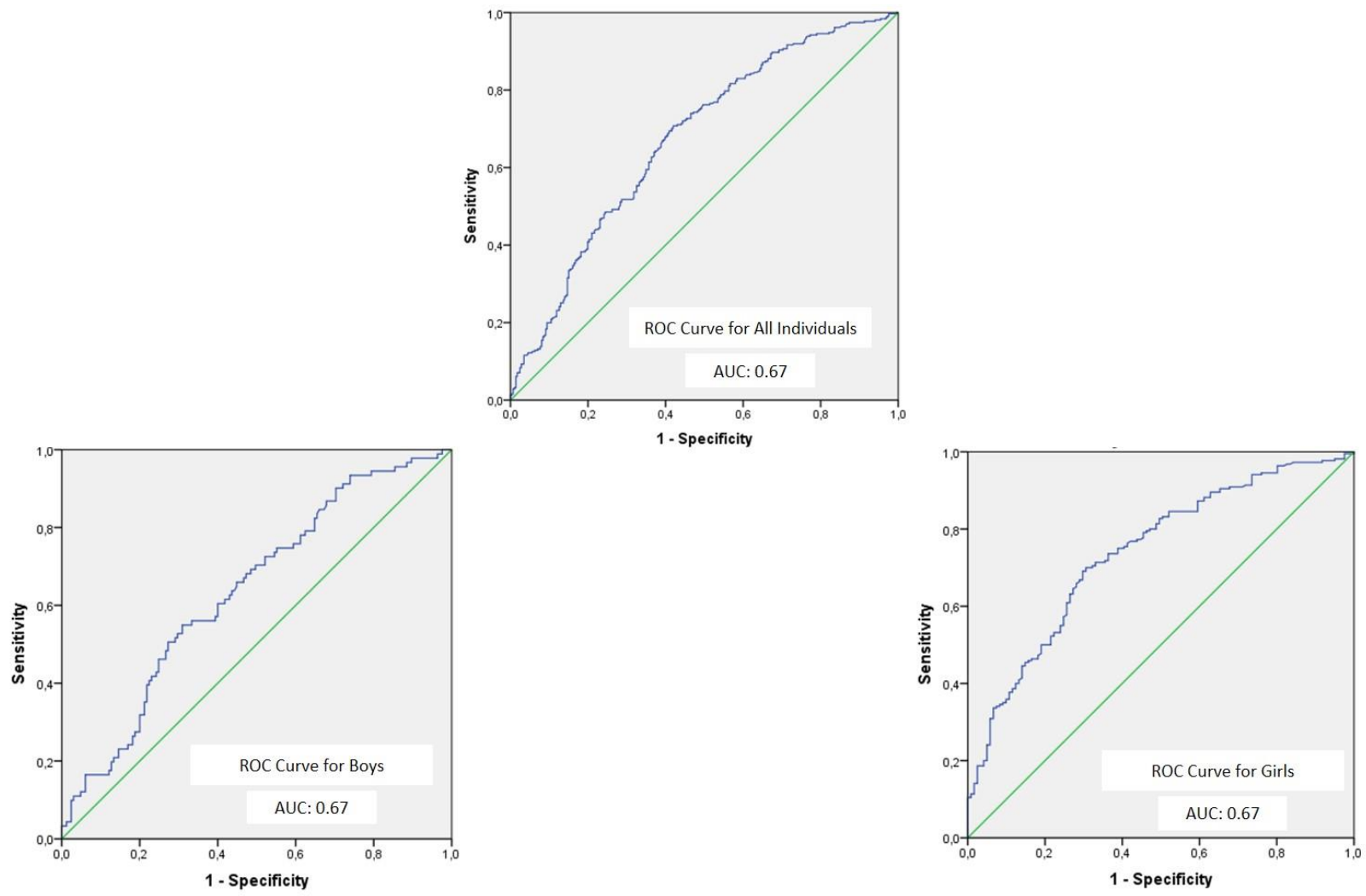

Figure 3: Receiver operating characteristic (ROC) curve of the effect of Ty-G index on detection of insulin resistance; It was calculated as 8.42 with $70.1 \%$ sensitivity and $59.3 \%$ specificity for all study groups; 8,38 with $71.1 \%$ sensitivity, and $48.3 \%$ specificity for boys; 8,27 with $80 \%$ sensitivity, and $52.9 \%$ specificity for girls

\section{DISCUSSION}

In this study, we found Ty-G index cutoff value for insülin resistance in pubertal obese children was 8.42 for all study groups, 8,38 for boys, and 8,27 for girls. On the other hand, there were significant correlations between Ty-G index and metabolic syndrome criteria (fasting insülin, cholesterol LDL, and HDL levels)

Insulin resistance is one of the most important factors in the pathogenesis of obesity-related metabolic complications, especially in Type $2 \mathrm{DM}$. In insulin resistance, there is a decrease in glucose uptake by muscle and adipose tissue, and suppression of hepatic glucose secretion ${ }^{12}$. The euglycemic clamp test is the recommended gold standard test for the diagnosis of insulin resistance in children and adolescents ${ }^{14}$. However, it is only used for research. Another frequently used method for assessing IR, in the oral glucose tolerance test, blood must be drawn at least 5 times, so it is timeintensive and not an easily practicable method because it is an invasive procedure. Because of these limitations, researchers have searched for easy-to-apply, simple, and highly specific tests for the investigation of IR, such as HOMA-IR, quantitative insulin sensitivity check index (QUICKI), and fasting glucose-insulin ratio $(\text { FGIR })^{14}$. There is no consensus on which cut-off should be taken in children and adolescents for HOMA-IR, which is one of the most used methods. On the other hand, it has an important limitation, because of the cut-off point changed by the pubertal stage. Recently, emerged studies have shown that the Ty-G index can accept as a marker of IR, that is correlated with both the euglycemic clamp test and the HOMA-IR levels ${ }^{7-9}$

There is a lot of study in adults investigating the Ty$\mathrm{G}$ index ${ }^{15-18}$. However, a limited study in pediatric age group ${ }^{19-24}$. Moreover, to the best of our knowledge, there is no study on Turkish children. Calcaterra et al. ${ }^{25}$ found that the cut-off value for the Ty-G index related to IR was considered 7.98 (sensitivity 60\%, and specificity 78\%; AUC 0.69 ), in their study of 541 children and adolescents aged 
$11.7 \pm 2.71$ yrs. In the same study, the authors suggested that the Ty-G index is not affected by gender and pubertal stage. In our study, we found similar cut-off values for boys and girls (8.38 vs 8.27). Moreover, similar cut-off values have been reached in a limited number of studies conducted in different countries (7.8-8.65) $)^{15-24}$. Moon et al. ${ }^{20}$ showed that 12-19 years old 8037 adolescents the cut-off values for the Ty-G index ranged from 8.158.65 in Mexican American, Non-Hispanic White, Korean, and Non-Hispanic Black adolescents. They also showed that a modest correlation between HOMA-IR and Ty-G index. In a cross-sectional retrospective study, it has been shown that higher central body adiposity and shorter time spent activities were related to increased Ty-G index in prepubertal children, and the calculated cutoff point in this study is found 7.88 (80\% sensitivity, $52 \%$ specificity $)^{26}$.

In a prospective study (followed up for $8.84 \pm 4.39$ years), Navarro-González et al. ${ }^{27}$ showed that Ty-G index is better than triglyceride or fasting glucose level for prediction of the Type 2 diabetes in normoglycemic individuals at baseline. It has been also shown that $\mathrm{Ty}-\mathrm{G}$ index may be considered as a predictive marker for atherosclerosis, hepatosteatosis, and cardiovascular disease ${ }^{28}$.

There is a strong relationship between adiposity and $\mathrm{IR}^{29}$. The prevalence of hepatic steatosis is highly prevalent in Type 2 diabetes patients ${ }^{30-31}$. Ryysy et al. ${ }^{32}$ showed that the insülin requirement of patients with Type 2 diabetes is significantly correlated with hepatic fat level. However, the exact mechanism of the insülin resistance in obese individuals has not yet been fully understood. The increased intracellular lipids in Skeletal Muscles may be related to insülin resistance ${ }^{33}$.

The study has some limitations. Firstly, we can not evaluate the cases diet because of the retrospective design, Secondly, we diagnosed insülin resistance according to HOMA-IR levels instead of euglycemic clamp test or OGTT.

In conclusion, $\mathrm{Ty}-\mathrm{G}$ index may be a reliable indicator for insülin resistance in pubertal obese adolescents. More attention should be given fort his marker with prospective studies.

\section{REFERENCES}

1. Apperley LJ, Blackburn J, Erlandson-Parry K, Gait L, Laing P, Senniappan S. Childhood obesity: A review of current and future management options [published online ahead of print, 2021 Nov 8]. Clin Endocrinol (Oxf). 2021;10.1111/cen.14625.

doi:10.1111/cen.14625

2. GBD 2015 Obesity Collaborators, Afshin A, Forouzanfar $\mathrm{MH}$, et al. Health Effects of Overweight and Obesity in 195 Countries over 25 Years. $N$ Engl J Med. 2017;377(1):13-27. doi:10.1056/NEJMoa1614362

3. Must A, Spadano J, Coakley EH, Field AE, Colditz G, Dietz WH. The disease burden associated with overweight and obesity. JAMA. 1999;282(16):1523-1529. doi:10.1001/jama.282.16.1523

4. Celik N, Cinaz P. Obezitenin Diğer Komplikasyonları. Turkiye Klinikleri J Pediatr Sci 2015;11(3):69-75

5. Guerrero-Romero F, Simental-Mendía LE, González-Ortiz M, Martínez-Abundis E, Ramos-Zavala MAG, Hernández- González SO et al. The product of triglycerides and glucose, a simple measure of insulin sensitivity. Comparison with the euglycemichyperinsulinemic clamp. J Clin Endocrinol Metabol 2010;95:3347-51

6. Conwell LS, Trost SG, Brown WJ, Batch JA. Indexes of insulin resistance and secretion in obese children and adolescents: a validation study. Diabetes Care. 2004;27(2):314-319. doi:10.2337/diacare.27.2.314

7. Simental-Mendía LE, Rodríguez-Morán $\mathrm{M}$, Guerrero-Romero F. The product of fasting glucose and triglycerides as surrogate for identifying insulin resistance in apparently healthy subjects. Metab Syndr Relat Disord. 2008;6:299-304.

8. Wan K, Zhao J, Huang H, et al. The association between triglyceride/high-density lipoprotein cholesterol ratio and all-cause mortality in acute coronary syndrome after coronary 
revascularization. $P L O S$

One.

2015;10(4):e0123521. Published 2015 Apr 16. doi:10.1371/journal.pone.0123521

9. Vasques AC, Novaes FS, de Oliveira Mda S, et al. TyG index performs better than HOMA in a Brazilian population: a hyperglycemic clamp validated study. Diabetes Res Clin Pract. 2011;93(3):e98-e100.

doi:10.1016/j.diabres.2011.05.030

10. Bundak R, Furman A, Gunoz H, Darendeliler F, Bas F, Neyzi O. Body mass index references for Turkish children. Acta Paediatr. 2006;95(2):194-198.

doi:10.1080/08035250500334738

11. Kurtoğlu S, Hatipoğlu N, Mazıcioğlu M, Kendirici M, Keskin M, Kondolot M. Insulin resistance in obese children and adolescents: HOMA-IR cut-off levels in the prepubertal and pubertal periods. J Clin Res Pediatr Endocrinol. 2010;2(3):100-106. doi:10.4274/jcrpe.v2i3.100

12. Freemark M. Childhood Obesity; in Brook C, Clayton P, Brown R, (eds): Brook's Clinical Pediatric Endocrinology. Wiley-Blackwell, 2009, pp 530-558.

13. Katz A, Nambi SS, Mather K, Baron AD, Follmann DA, Sullivan G, et al.Quantitative insulin sensitivity check index: a simple, accurate method for assessing insulin sensitivity in humans. J Clin Endocrinol Metab. 2000 Jul;85(7):2402-10

14. Darendeliler F. Beta Hücreleri İşlevleri ve İnsülin Duyarlılığının değerlendirilmesi: Bazal Ölçümlerin Değerlendirilmesi ve Glukoz Klemp Testi.In: Yordam N, Alikaşifoğlu A, Bideci, editors. Çocuk ve Adolesanda Endokrin Testler. 1st ed. Ankara, Güneş Kitabevi, 2006:69-76

15. Malek M, Khamseh ME, Chehrehgosha H, Nobarani S, Alaei-Shahmiri F. Triglyceride glucose-waist to height ratio: a novel and effective marker for identifying hepatic steatosis in individuals with type 2 diabetes mellitus. Endocrine. 2021;74(3):538-545. doi:10.1007/s12020-021-02815-w

16. Mirr M, Skrypnik D, Bogdański P, Owecki M. Newly proposed insulin resistance indexes called TyG-NC and TyG-NHtR show efficacy in diagnosing the metabolic syndrome. $J$ Endocrinol Invest. 2021;44(12):2831-2843. doi:10.1007/s40618-021-01608-2

17. Liu Y, Chi R, Jiang Y, Chen B, Chen Y, Chen Z. Triglyceride glycemic index as a biomarker for gestational diabetes mellitus: a systemic review and meta-analysis. Endocr Connect. 2021;10(11):1420-1427. Published 2021 Nov 5. doi:10.1530/EC-21-0234

18. Kim J, Shin SJ, Kang HT. The association between triglyceride-glucose index, cardiocerebrovascular diseases, and death in Korean adults: A retrospective study based on the NHISHEALS cohort. PLoS One. 2021;16(11):e0259212. Published 2021 Nov 4. doi:10.1371/journal.pone.0259212

19. Rodriguez-Moran M, Simental-Mendia LE, Guerrero-Romero F. The triglyceride and glucose index is useful for recognisinG insulin resistance in children. Acta Paediatr. 2017;106:979-83.

20. Moon S, Park JS, Ahn Y. The Cut-off Values of Triglycerides and Glucose Index for Metabolic Syndrome in Americanand Korean Adolescents. J Korean Med Sci. 2017;32:427-33.

21. Kang B, Yang Y, Lee EY, Yang HK, Kim HS, Lim SY, et al. Triglycerides/glucose index is a useful surrogate marker ofinsulin resistance among adolescents. Int $\mathrm{J}$ Obes (Lond). 2017;41:789-92. 
22. Kim JW, Park SH, Kim Y, Im M, Han HS. The cutoff values of indirect indices for measurinG insulin resistance for metabolic syndrome in Korean children and adolescents. Ann Pediatr Endocrinol Metab. 2016;21:143-8.

23. Cho J, Hong H, Park S, Kim S, Kang H. Insulin Resistance and Its Association with Metabolic Syndrome in Korean Children. Biomed Res Int. 2017;2017:8728017.

24. Simental-Mendía LE, Hernández-Ronquillo G, Gómez-Díaz R, Rodríguez-Morán M, GuerreroRomero F. The triglycerides and glucose index is associated with cardiovascular risk factors in normal-weight children and adolescents. Pediatr Res.2017;82:920-5.

25. Calcaterra, V., Montalbano, C., de Silvestri, A., Pelizzo, G., Regalbuto, C., Paganelli, V., Albertini, R., Cave, F. D., Larizza, D., \& Cena, H. (2019). Triglyceride Glucose Index as a Surrogate Measure of Insulin Sensitivity in a Caucasian Pediatric Population. Journal of clinical research in pediatric endocrinology, 10.4274/jcrpe.galenos.2019.2019.0024.

Advance online publication.

26. Vieira-Ribeiro SA, Fonseca PCA, Andreoli CS, et al. The TyG index cutoff point and its association with body adiposity and lifestyle in children. J Pediatr (Rio J). 2019;95(2):217-223. doi:10.1016/j.jped.2017.12.012

27. Navarro-González D, Sánchez-Íñigo L, Pastrana-Delgado J, Fernández-Montero A, Martinez JA. Triglyceride-glucose index (TyG index) in comparison with fasting plasma glucose improved diabetes prediction in patients with normal fasting glucose: The Vascular-
Metabolic CUN cohort. Prev Med. 2016;86:99105. doi:10.1016/j.ypmed.2016.01.022

28. Brito ADM, Hermsdorff HHM, Filgueiras MS, et al. Predictive capacity of triglyceride-glucose (TyG) index for insulin resistance and cardiometabolic risk in children and adolescents: a systematic review. Crit Rev Food Sci Nutr. 2021;61(16):2783-2792. doi:10.1080/10408398.2020.1788501

29. Kelley DE, Goodpaster BH. Skeletal muscle triglyceride. An aspect of regional adiposity and insulin resistance. Diabetes Care. 2001;24(5):933-941.

doi:10.2337/diacare.24.5.933

30. Marceau P, Biron S, Hould FS, et al. Liver pathology and the metabolic syndrome $\mathrm{X}$ in severe obesity. J Clin Endocrinol Metab. 1999;84(5):1513-1517. doi:10.1210/jcem.84.5.5661

31. Marchesini G, Brizi M, Morselli-Labate AM, et al. Association of nonalcoholic fatty liver disease with insulin resistance. Am $\mathrm{J}$ Med. 1999;107(5):450-455. doi:10.1016/s00029343(99)00271-5

32. Ryysy L, Häkkinen AM, Goto T, et al. Hepatic fat content and insulin action on free fatty acids and glucose metabolism rather than insulin absorption are associated with insulin requirements during insulin therapy in type 2 diabetic patients. Diabetes. 2000;49(5):749-758. doi:10.2337/diabetes.49.5.749

33. Yuan ZM, Li M, Ji CY, Li L, Jia L, Incecik A. Steady hydrodynamic interaction between human swimmers. $J \quad R \quad S o c$ Interface. 2019;16(150):20180768. doi:10.1098/rsif.2018.0768 